\title{
The Victoria and Alfred Waterfront as playground for Capetonians
}

\author{
Sanette Ferreira \\ Rozitta de Villiers \\ Sanette Ferreira, Stellenbosch University, Department of Geography and Environmental Studies \\ (slaf@sun.ac.za) \\ Rozitta de Villiers, Masters'student in the Department of Geography and Environmental Studies at Stellenbosch \\ University

\begin{abstract}
The paper contributes to the exploration and understanding of the social geographies of public space in the Victoria \& Alfred Waterfront (V\&AW) in Cape Town. The aim is to understand Capetonians' (visitors and employees) perceptions of the V\&AW as public, leisure, shopping and working spaces. The appropriate literature on waterfront developments in providing public, working and leisure space is reviewed. Two questionnaire surveys (visitors and employees) as well as eight unstructured interviews with important role players in the tourism industry of Cape Town were conducted. Findings revealed the most important reasons for Capetonians to visit or use certain spaces in the V\&AW, the public open spaces they liked and how they perceived the V\&AW as an inclusive space. The research also sought the respondents' views on how the certain public spaces can be improved; what new activities and retail shops can be introduced; their opinions about the affordability of restaurants and parking; and how the V\&AW can improve to cater for the needs of the Waterfront's employees. Recommendations are made for making the V\&AW more functional and accessible to Capetonians.
\end{abstract}

Keywords: Cape Town, waterfronts, leisure, tourism, shopping space and public space

\section{Introduction}

The past four decades have witnessed many waterfront transformations from places where shipping and heavy industry dominated into spaces for residential, commercial and leisure activities (Gospondini, 2006; O’Callaghan \& Linehan, 2007; Casellas, Dot \& PallaresBarbera, 2012). The challenge to port cities undertaking waterfront redevelopments is to reclaim the port areas and transform them into areas of economic growth, spaces where public health and the environment are protected and to create a sense of place that attracts the local community to use the public open spaces the developments offer (Quinn, 2012).The Victoria and Alfred Waterfront (V\&AW) in Cape Town had been transformed from a brownfields shipping wasteland to a mixed-use development boasting public spaces of distinction. The V\&AW now includes tourism attractions, retail space (shopping space), office space, restaurants, accommodation establishments, entertainment facilities, commercial property and a variety of residential properties (V\&A Waterfront, 2011). This redevelopment and ongoing development (eighth phase - also called silo-development) has received the attention of international (Breen \& Rigby, 1996; Lemanski, 2007; Houssay-Holzchuch \& Teppo, 2009; Eidelman 2013 ) and local scholars (Kilian \& Dodson, 1996; Van Zyl, 2006; Ferreira \& Visser 2007; Pirie, 2007; Rogerson \& Visser, 2007).

The V\&AW is the most visited tourism and leisure space in South Africa. It received over 24 million visitors in 2013 (White, 2014) and the visitor profile in 2011 revealed a local, national and international mix with approximately 55\% of the visitors being Capetonians, 
29\% foreign and 16\% South African visitors from beyond the boundaries of the Cape Town metropolitan area (Cole, 2014). The V\&AW is not only a key destination for domestic visitors to Cape Town as it is also a popular site for the leisure activities of Capetonians (Rogerson \& Visser, 2007).

The original purpose of the development was to transform the former harbour area into a safe public space that would be commercially viable and would reconnect the harbour with the city centre (Birkby, 1998). Other objectives of the redevelopment were to generate employment and to develop the public spaces in the V\&AW in a way that locals would feel welcome to visit these leisure spaces. Access has often been a key concern of critics of waterfront developments (Lehrer \& Laidley, 2008). In the first years of the V\&AW's redevelopment, it was predominately "a white man's playground” but the V\&AW has since expanded its appeal to include at least lower-middle-class cohorts and, on occasion, even the poor (Ferreira \& Visser, 2007). However, "whatever the critics might say, anyone with Levi's jeans, T-shirt, and good sneakers is welcome at the V\&AW" (Ferreira \& Visser, 2007: 241). Access to (and some aspects of the consumption of) the redeveloped space (as opposed to full participation) is not nearly as exclusionary as critics would lead one to believe about waterfronts, if not generally, then certainly the V\&AW (Ferreira \& Visser, 2007). The V\&AW employs a wide variety of staff in various business categories and with different skills levels, who work there daily and often spend their lunch hours shopping or at leisure in a variety of public open spaces. From a spatial perspective, it is false to argue that the V\&AW is inaccessible regarding its physical location as the $\mathrm{V} \& \mathrm{AW}$ is one of the most accessible locations in Cape Town and well serviced by both private and public transport. However, some local visitors perceive the V\&AW to be a tourist trap aimed at high-income earners and international visitors. Although many local visitors have an emotional connection with the property, they do not necessarily make it their shopping destination of choice (HoussayHolzchuch \& Teppo, 2009). The V\&AW consists of a variety of public spaces but Capetonians do not find all to be functional and some have no reason to visit the V\&AW. The V\&AW regeneration was primarily investment led and while a part of the old commercial port was converted into an upmarket mixed-use development, some Capetonians perceived it as a playground for high- income earners. Against these criticisms of the exclusiveness and expensiveness of the V\&AW, the overarching aim of the research reported here was to investigate, understand and evaluate the perceptions Capetonians have on the leisure, recreation, shopping and working spaces of the V\&AW. First, we review the appropriate theory on waterfront developments in port cities regarding their role as public, work and leisure spaces. Second, we explain the mixed-method research approach which includes a spatial analysis of land use in the V\&AW; two questionnaire surveys (Capetonians who visit the V\&AW and employees in different business sectors at the V\&AW) to determine the perceptions of these groups of individuals about certain spaces at the V\&AW; and unstructured interviews with important role players in the tourism industry of Cape Town, to detect their views on these spaces. Third, findings are presented and interpreted. Last, the main findings are discussed and synthesised and conclusions are drawn.

\section{Public space in waterfront cities}

Public spaces are a fundamental feature of cities and are generally owned and managed by public agencies. Areas to which the public has access (such as roads, streets, lanes, parks, squares and bridges) make up the 'public realm'. This includes the publicly accessible space between buildings, along with the spaces and the buildings or other structures that enclose them (Dublin City Council, 2011). Public spaces are often viewed as empty or residual spaces - areas between buildings and open to all forms of public use. Public spaces are "breathing zones built into the heart of the city” (Nikitini, 2011, p.21). Today, a variety of semi-public 
spaces are managed by private-public partnerships - this questions the concept of public spaces - as spaces accessible to the public (Tonnelat, 2010). The use of public spaces varies with the community which they serve. In some societies public spaces are used for leisure activities (drinking coffee or wine at a street cafe) and in developing countries, some of the citizens live in informal settlements and use these open spaces for socialising or informal markets (Nikitin, 2011). Ideally, public spaces are open spaces shared by the whole community, spaces that are open to all without discrimination (Nikitin 2011). Moreover, they are spaces that can be shared by all, spaces for informal socialising or meetings, places where people can come and go freely (Cattel et al., 2008). Public spaces contribute to continuity of urban environments as they are often a link between buildings and neighbourhoods. They are a fundamental factor in encouraging social cohesion among communities. They are spaces where people meet; human interaction takes place; and they form a constructive part of the image of cities. Public spaces are often designed to showcase the historical and cultural landscapes as well as the natural surroundings of cities. Main public spaces usually act as gateways to cities by attracting investors and tourists and they are used to project a positive image of a city (Madanipour, 2004). Unfortunately, because of declining central areas of some cities, the lives of users of these spaces are at risk and in some cases users of these spaces can be 'othered' (Young 1995). Amin (2006) posits a positive view of these spaces in urban areas by considering them as sites of association and as "sites of civic promise" (Amin, 2006: 1020).Typically, waterfront developments are regarded as shared space about which different groups often hold highly contrasting views (Hoyle, 1995, 2002). Different users of public spaces attain a sense of well-being for different reasons. Social interaction in spaces can provide relief from daily routines, give sustenance for people's sense of community, offer opportunities for sustaining bonding ties or making bridges, positively influence tolerance and raise people's spirits. These spaces represent sites for socialising and face-to-face interaction, and at the same time their quality is commonly perceived to be a measure of the quality of urban life (Cattel et al., 2008). Cattel et al. (2008, p. 544) see public spaces as: "Places of escape; social interaction; vibrant social arenas; inter-ethnic interaction and understanding." Local-community perspectives on waterfront developments are often rather different from those of developers, politicians, planners, port authorities and environmentalists. In the case study reported here the perceptions of local Capetonians of the V\&AW are analysed.

\section{V\&AW in Cape Town: A place for work, shopping and leisure Study area}

The re-establishment of physical links between Cape Town and its waterfront has created a quality environment: a desirable place to work, live and play as well as giving Capetonians pride. "It has exceeded all expectations, and it has earned its place as South Africa's most visited destination" (Van Zyl 2006, p. 2). The V\&AW is located on the edge of Cape Town's harbour and in relative proximity to the iconic Table Mountain, Robben Island, Cape Town Stadium and the Cape Town International Convention Centre (CTICC) (Figure 1). The V\&AW borders the central business district (CBD), Greenpoint, Duncan Dock, the Atlantic Ocean and Granger Bay. For the purposes of this study, the marine residential apartments situated in the Marina Basin are excluded. The surface area of the V\&AW is $604,000 \mathrm{~m}^{2}$ which includes $46,000 \mathrm{~m}^{2}$ of retail, $130,000 \mathrm{~m}^{2}$ office, $7,000 \mathrm{~m}^{2}$ entertainment, $13,000 \mathrm{~m}^{2}$ museums, $250,000 \mathrm{~m}^{2}$ residential and $98,000 \mathrm{~m}^{2}$ fishing industry space as well as public space (V\&AW, 2013). The latter public space includes a variety of 'precincts' of which ten are used for outside events and exhibitions areas, another six are used as promotional courts and are situated inside the Victoria Wharf Shopping Centre. The study concentrates on eight 'open air' public spaces and their uses (Table 1). Other public areas at the V\&AW include the newly established boardwalk - built along the Granger Bay beach area with viewing points and 
benches, and two jogging routes (2.5 and 5km). In the Clock Tower precinct (Silo Square) a cruise liner terminal and jetty are planned to be completed in 2016. In 2012 the V\&AW had 649 tenants employing 16, 764 people directly (permanent and temporary staff) (Standish et al, 2013).

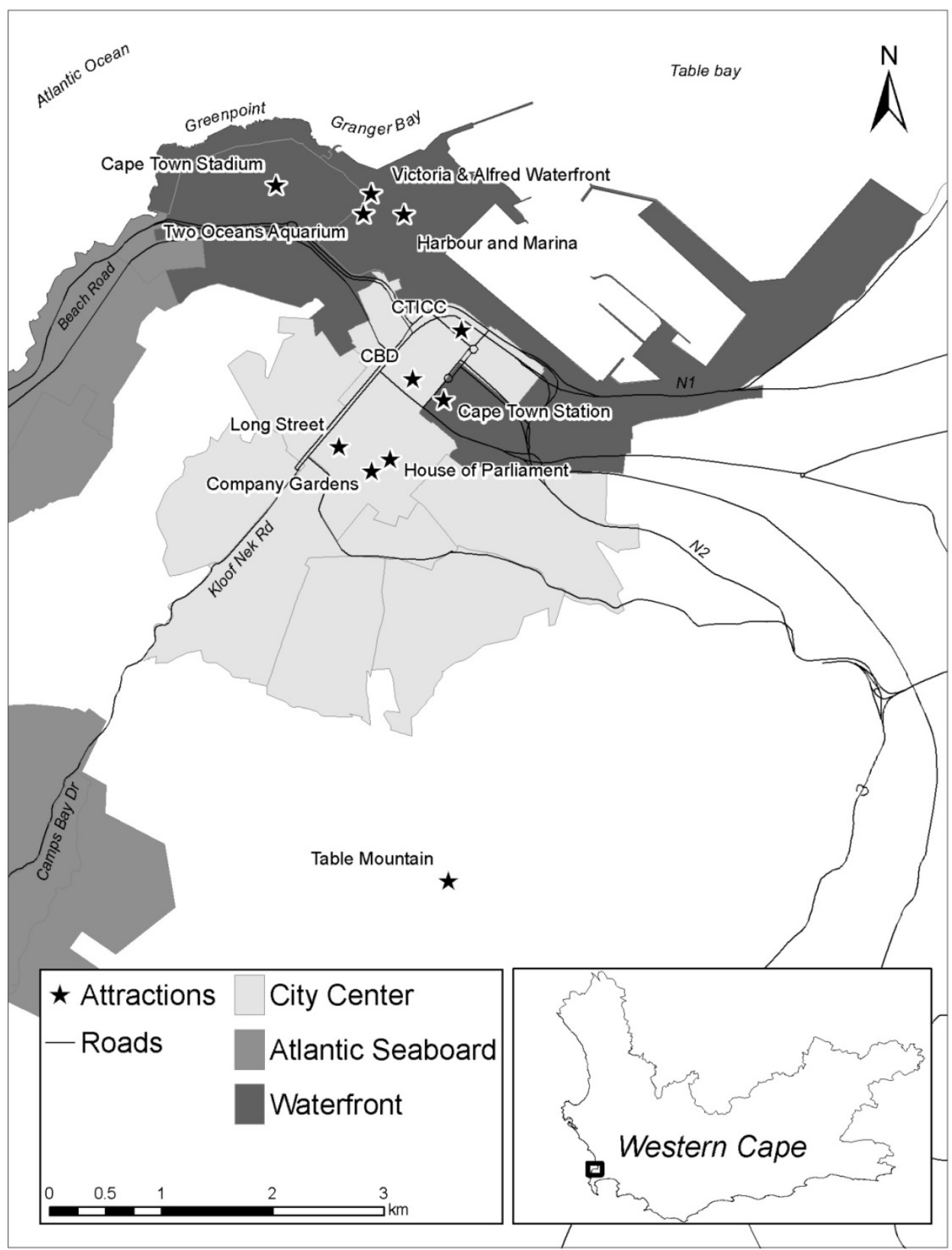

Figure 1: The V\&AW in its urban context.

Table 1: Open-air public spaces at the V\&AW.

\begin{abstract}
Amphitheatre
The amphitheatre consists of $123 \mathrm{~m}^{2}$ of covered stage surrounded by concrete seating. The area has capacity for 2,000 seated spectators and 5,000 standing. The area is used to host a variety of live performances, media events and interactive promotions. The amphitheatre also hosts a 5.36m-wide x 2.88m-high LED daylight screen with a 160-degree view used to display specific messages aimed at visitors.
\end{abstract}

\title{
Pier-head
}

This is a $25 \mathrm{~m}^{2}$ area is situated on the historical harbour which was part of the first development of the V\&AW. 
The area includes a small amphitheatre and is used to host small public events and as a viewing point for marine activities on Quay 5 and Jetty 1 (e.g. Volvo Ocean Yacht Race, Red bull Flugtag, etc.).

\title{
North Wharf
}

This $1,123 \mathrm{~m}^{2}$ quayside area is situated in the Marina Basin. It is a multipurpose space for hosting a wide variety of events given its proximity to the Marina Basin. Previous events include the Blessing of the Portuguese fishing fleet, dragon-boat races, Cape Town Boat Show, a Summer Concert series and Aqua Opera (the event consisted of a stage floating the Marina Basin and supported by a 2,000-seater pavilion on North Wharf.

\section{Croquet Lawn}

Situated at Portswood on top of the Ulundi Parking Garage. The area consists of $800 \mathrm{~m}^{2}$ of lawn and is used for private and public events with great consideration for the well-being of the lawn. Public events include croquet. During the coming festive season (2014/15) the area is earmarked to host an open-air theatre for showing movies to general public under the stars.

\section{Historic Tunnel}

Situated at Portswood Ridge and only used for small private functions. The area was originally an open tunnel cut through the ridge to transport rock in cocopans from the current Marina Basin area to the Breakwater, during the latter's construction in 1860. The tunnel was later covered for use as an air-raid shelter during World War II but luckily never used for this purpose. The area was later used as a small winery, Flagstone Wines, and then for additional brewing space for Ferryman's Brewery.

Breakwater Boulevard Site
The area consists of lawn situated between the Breakwater Parking Garage and Granger Bay beach area. The
area is $1,000 \mathrm{~m}^{2}$ in size and used for private events and functions. An international company recently used the site
to host a recruitment drive.

\section{Clocktower Square}

Situated in the Clock Tower precinct, the square is used to host a variety of private and public events and functions. Previous uses of this area include a viewing area for the 2010 FIFA Soccer World Cup, vehicle launches, charity events and children's entertainment. The space is currently divided in two. One site is occupied by Moyo Restaurant and its semi-permanent informal food market called a "souk". The other half is used to host a variety of events, such as the Chelsea Flower Show exhibition in September 2013.

\section{Market Square}

Situated in the heart of the V\&AW, adjacent to the amphitheatre and children's play area. The area is currently the semi-permanent home to the Cape Wheel but it use to host a variety of public and private events, e.g. Volvo Yacht Race exhibition, beach volleyball, children's events, Wine Festival, Khoi Fish Festival and even a haunted house. The central location of this area makes it very accessible to the public and therefore popular with event organisers.

\section{Nobel Square}

Named after the four South African Nobel Peace prize winners, Albert Luthuli, Desmond Tutu, FW de Klerk and Nelson Mandela. The small square situated between the Market on the Wharf and the V\&A Hotel have spectacular views of Table Mountain and the Alfred Basin. The square is usually used for small cultural events related to the Nobel Laureates.

\begin{abstract}
Amsterdam Site
The remains of the Amsterdam Battery have been found on this site and date from the same period as the Chavonnes Battery. V\&A management decided to cover the remains to protect the area until they have the resources to do proper excavations. The concrete slate adjacent to the Battery is used for a variety of public and private events, e.g. 2010 FIFA Soccer World Cup viewing area, extreme skateboarding events, and parking for large busses, film crews and overflow parking for the Cape Town International Convention Centre (Moolman, 2013).
\end{abstract}

Note: The location of each of these public spaces is shown in Figure 2.

The richness and variety of public open spaces at the V\&AW provides a real world stage for local Capetonians to interact, leisure and enjoy some 'breathing space' between the ocean and the city. In the next section the mixed method research approach is explained.

\section{Research methods}

The first step was to review the appropriate literature on waterfront developments and public open spaces as well as the transformation of the V\&AW from 'port to playground' - a redevelopment of redundant dockyards to a world-class waterfront development providing 
public, working and leisure spaces. The second step was the administering of two questionnaire surveys, one of local Capetonian visitors to the V\&AW and the second among employees working for companies located in the V\&AW in different sectors on three employment levels. The visitor questionnaire included three sections on V\&AW-specific information (14 questions), geographical information (six questions) and biographical information (three questions). The fourteen questions in the first section enquired about primary reasons for visiting the V\&AW; types of business and leisure activities; duration of stay; sleepovers at hotels in the V\&AW; favourite parts of the V\&AW; favourite public spaces; uses of public spaces; special memories of certain spaces; with whom they spent time at the V\&AW; and suggestions for improving the V\&AW. The six questions in the second section elicited information about where the respondents live, where they are employed, where they do their monthly and daily convenience shopping, the name of their favourite shopping centre and where they engage in leisure activities. The last section asked questions on gender, age and whether the respondents had children. The employee questionnaire asked the same questions posed to visitors but added a section on employment information enquiring about sector of employment, employment level, number of years worked in the V\&AW, time away from office during working hours (spent in other activities at V\&AW) and time spent at V\&AW outside working hours (before work, during lunch break, after hours).

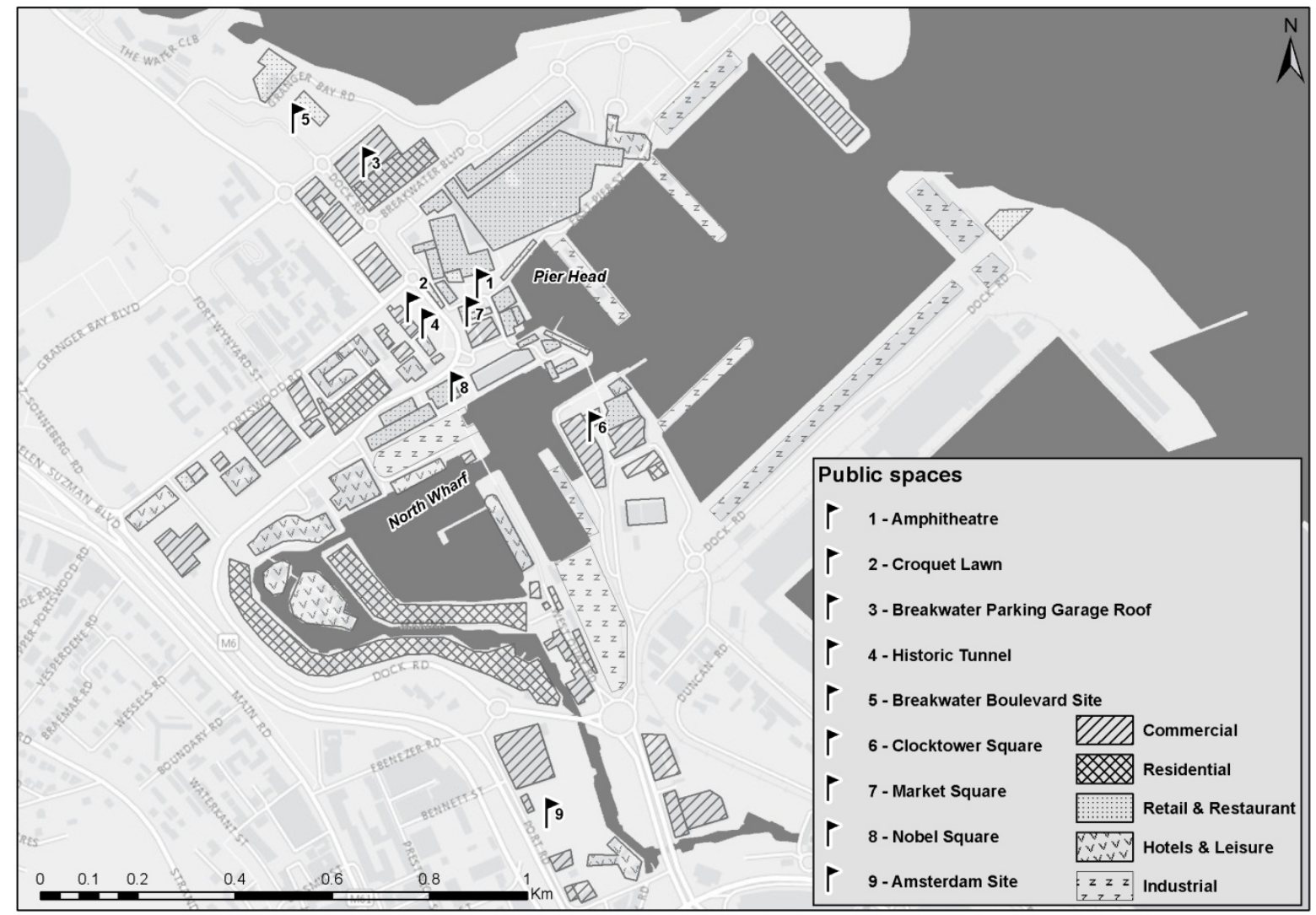

Figure 2: Land uses and public open spaces in the V\&AW.

Within the constraints of time and funds, a convenience sampling approach with a target quota of at least 150 completed questionnaires for each subgroup was followed. The two questionnaires were distributed differently. The employee questionnaire survey used a stratified approach. All employees at the V\&AW were divided into business sectors and according to the relative proportion (percentage) of the total employment population (e.g. if 
retail jobs represented $41 \%$ of total employment at the $\mathrm{V} \& \mathrm{AW}$, then $41 \%$ of the total respondents in this sub group has to come from the retail sector). Employee respondents were further stratified into three groups: senior managers (or business owners), middle management and frontline staff. Distribution of questionnaires took place by contacting every company individually by e-mail and those willing to take part in the project were given questionnaires and their human resource managers asked to distribute them to employees in a specific category. Completed questionnaires were collected later. Over 600 questionnaires were distributed to this group before the quota of 150 completed questionnaires was reached. For the visitor respondents email addresses were distilled from the V\&AW Company's database of visitors. To ensure that respondents were included from high-, middle- and lowincome suburbs, the selection process purposely included respondents from a wide geographical spread. The visitor questionnaires were distributed in three ways: online by inviting people through social media (Facebook); direct email correspondence; and hard copies per hand. This was done over a period of three months with continuous follow-ups, reposting of the link to the questionnaire and repeated requests for invitees to respond. Visitors to the V\&AW who were personally known to the researchers were not asked to participate. A total of 150 completed questionnaires were received. The third step in data collection process was the conducting of unstructured interviews with eight important role players in the tourism industry of Cape Town.

\section{Profiles of respondent groups (visitors and employees)}

The gender profile of the visitor respondents is $66 \%$ female and $34 \%$ male whereas the employee profile shows a greater male (39\%) representation than that of visitors (Figure 3a). The majority of respondents (41\%) are between the ages of 25 and 35 years old, with another $38 \%$ between the ages of 36 and 45 years and the rest of the respondents were older than 45 (Figure $3 \mathrm{~b}$ ). The employees represent different business sectors (Figure 4) of which most are in the commercial (including financial, fishing and marina businesses) and retail sectors.

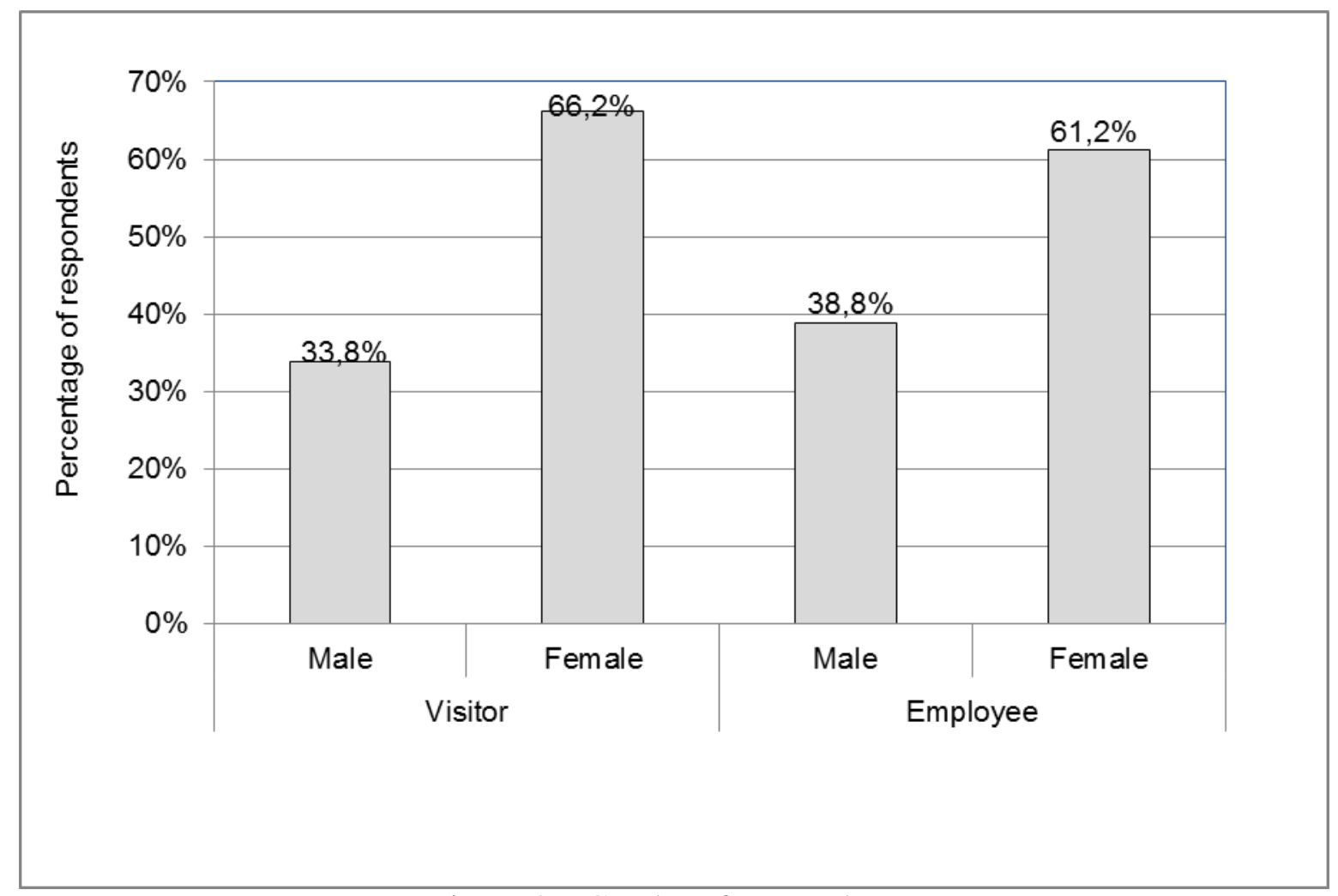

Figure 3a: Gender of respondents. 


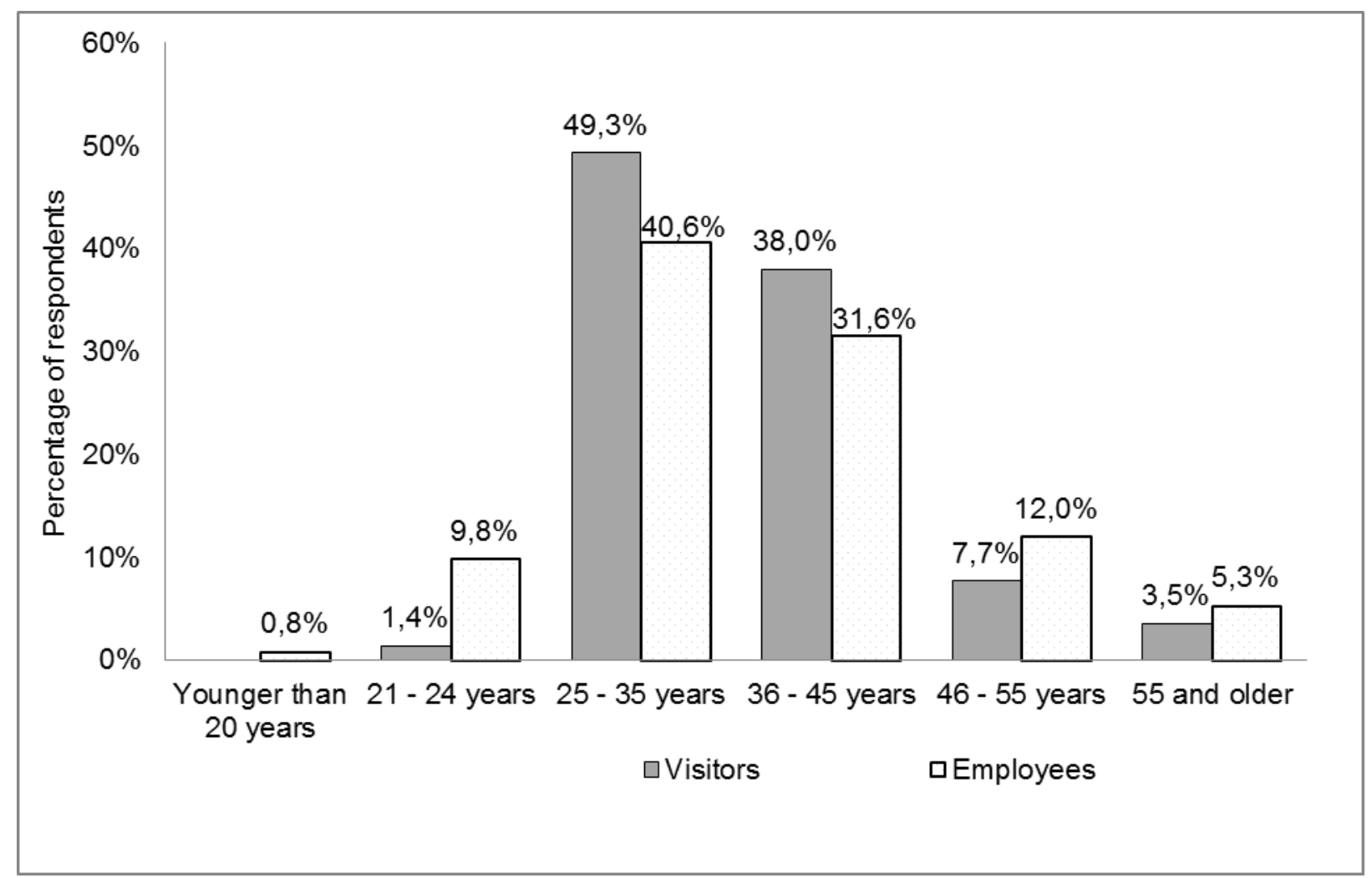

Figure 3b: Age of respondents.

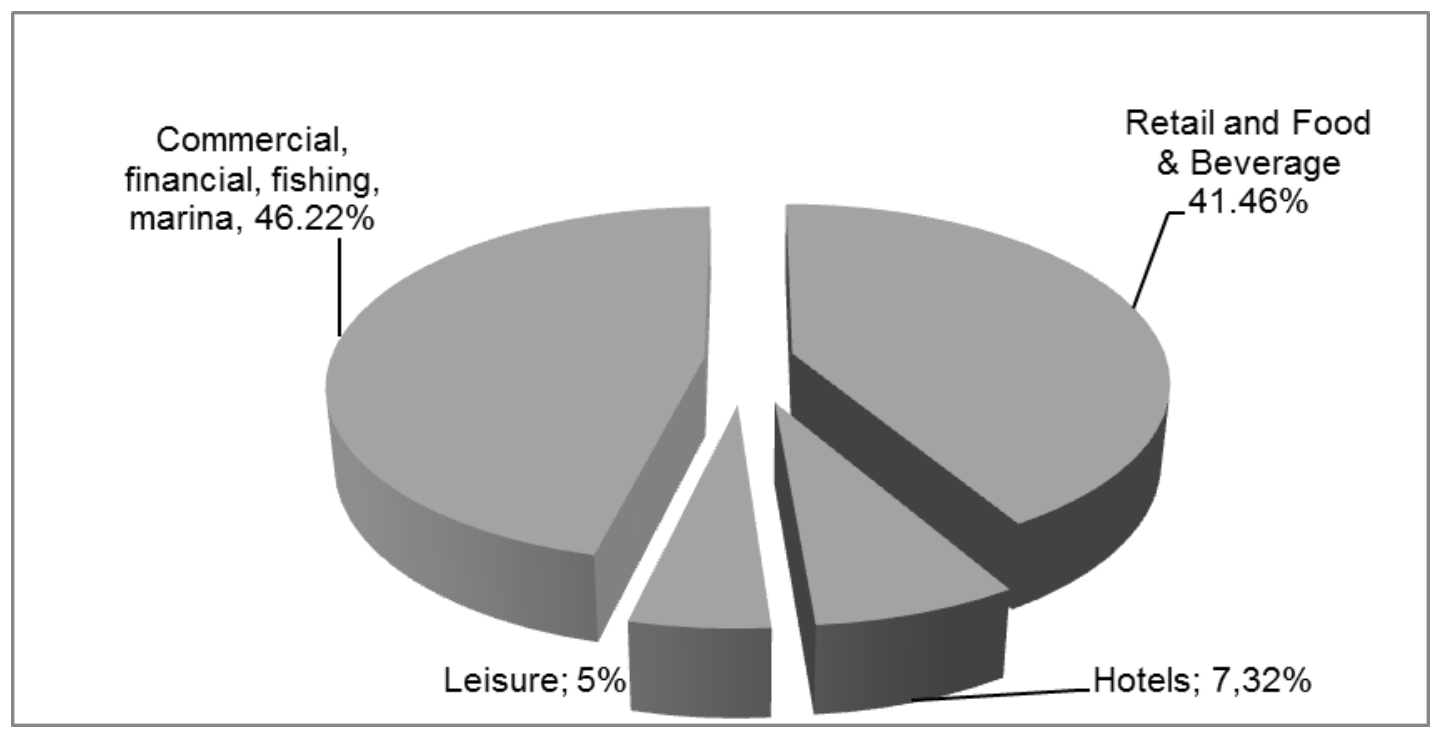

Figure 4: Employee respondents per business sector.

\section{The V\&AW as a place to visit, work, relax and do shopping}

Many port cities have, over the past three decades, reclaimed their waterfronts and transformed them into areas that contribute to economic growth, provide leisure space for their local communities to mingle with other citizens so contributing to the quality of urban life of these citizens (Robinson, 2012; Quinn, 2012). Following its transformation and redevelopment, the V\&AW was assessed to be very exclusive and a "white man's playground" (Lemanski, 2005) and although Ferreira and Visser (2007: 241) counter claimed that the V\&AW had expanded its appeal to include "at least lower-middle-class cohorts and, on occasion, even the poor", there are still those who perceive the V\&AW as a tourist trap (Dave, 2011). In the following paragraphs the results of two questionnaire surveys are 
examined to uncover how the Capetonian respondents (visitors and employees) think about, view and experience the V\&AW.

\section{Visitor and employee views on the V\&AW}

The V\&AW provides locals with a vast array of options for eating out at restaurants, shopping and enjoying entertainment. The visitor respondents indicated that the most important reasons for visiting the V\&A are to eat at a restaurant, do shopping or to participate in a leisure activity (Figure 5a). For employees working at the V\&AW, shopping, doing business and eating at a restaurant are the most important reasons for visiting the V\&AW during their free time (Figure 5b).

Both respondent groups were asked how often they visited the V\&AW and for how long. Overall, both groups indicated that they visited the V\&AW at least once per month to do shopping, or to visit a restaurant or a coffee shop. Those who visited the V\&AW daily stayed for less than an hour and to up to two hours a time, while those who visited the V\&AW less frequently stayed longer, e.g. three to four hours or even longer. It appears that those who visit the V\&AW for shorter periods may do so for convenience shopping or to have a quick meal, while those visiting for longer most probably do so for leisure purposes. Visitors indicated that they only purchase take away meals at the V\&AW once a month, while employees did so once per week. Visitors liked to relax and enjoy the view, whereas employees never did so. The main reason for employee not visiting the V\&AW over weekends was that parking is too expensive.

To assess how Capetonians perceive certain areas in the V\&AW, respondents were asked to indicate their liking of nine areas (working harbour, shopping mall, craft markets, free entertainment areas, restaurants, hotels, public spaces, coffee shops and scenic views from benches on the quayside). Local visitors responded that they like the shopping mall, followed by the restaurants and free entertainment areas. A very small percentage of the local visitors did not like the craft markets, the working harbour and free entertainment areas. Employees responded that they like scenic views from benches on the quayside, the shopping malls and restaurants. The craft markets, working harbour and free public spaces were not liked by a very small group of employees. It is noteworthy that employees indicated that they do not spend time enjoying the scenic beauty but when asked if the like this feature of V\&AW they responded that they liked it most. Members of this group quite likely do not have the time to enjoy the scenic views, yet they find it appealing.

The local visitors and employees were also asked about their liking of seven public spaces in the V\&AW, how they interact with each and to suggest how use of public spaces can be improved. Figures $6 \mathrm{a}$ and $6 \mathrm{~b}$ indicate how many of each respondent group respectively liked or did not like the seven public spaces (Amphitheatre, Market Square, Clock Tower Square, Nobel Square, Food Court, Pier Head and North Wharf). 


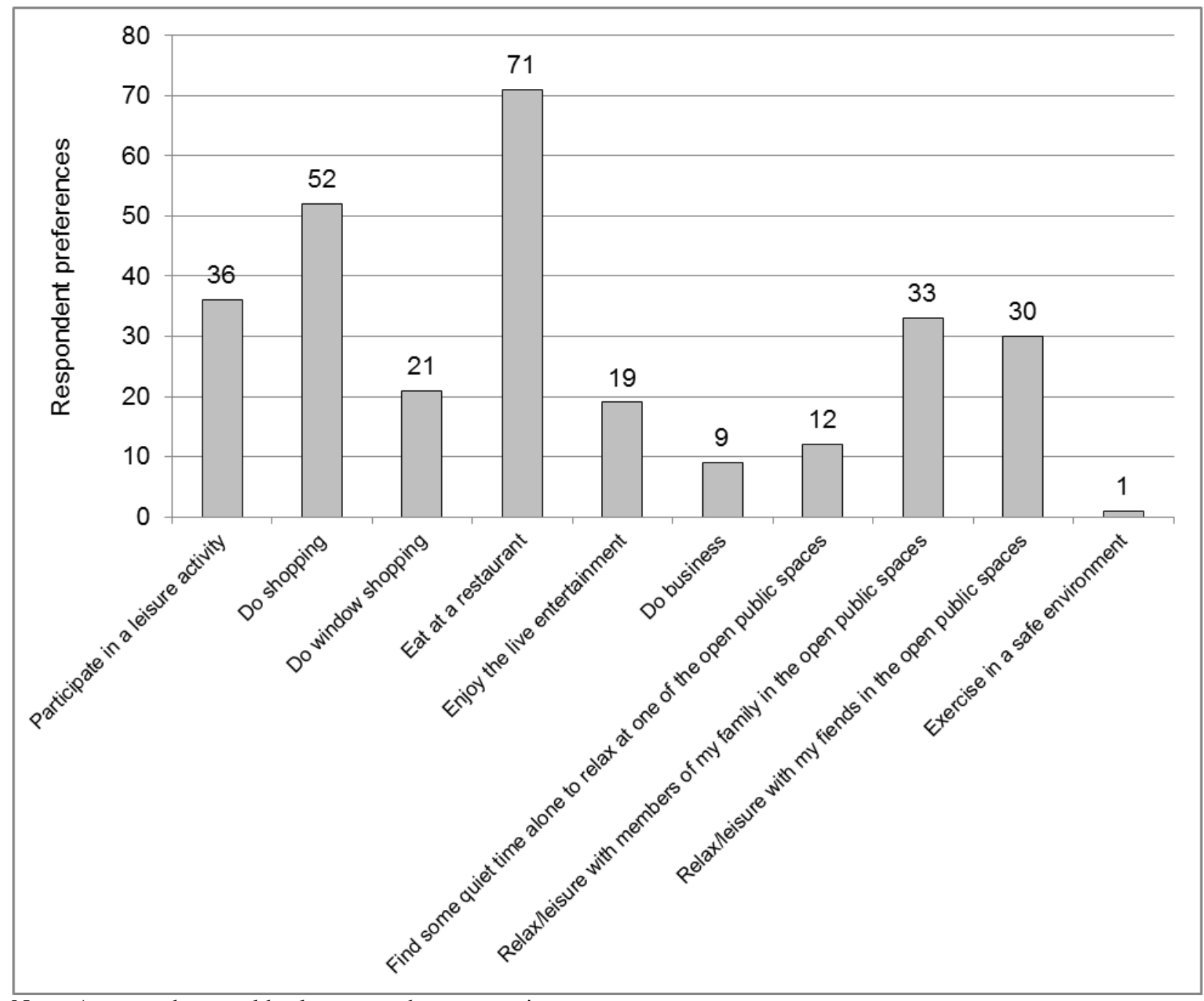

Note: A respondent could select more than one option

Figure 5a: Reasons why Capetonians visit the V\&AW.

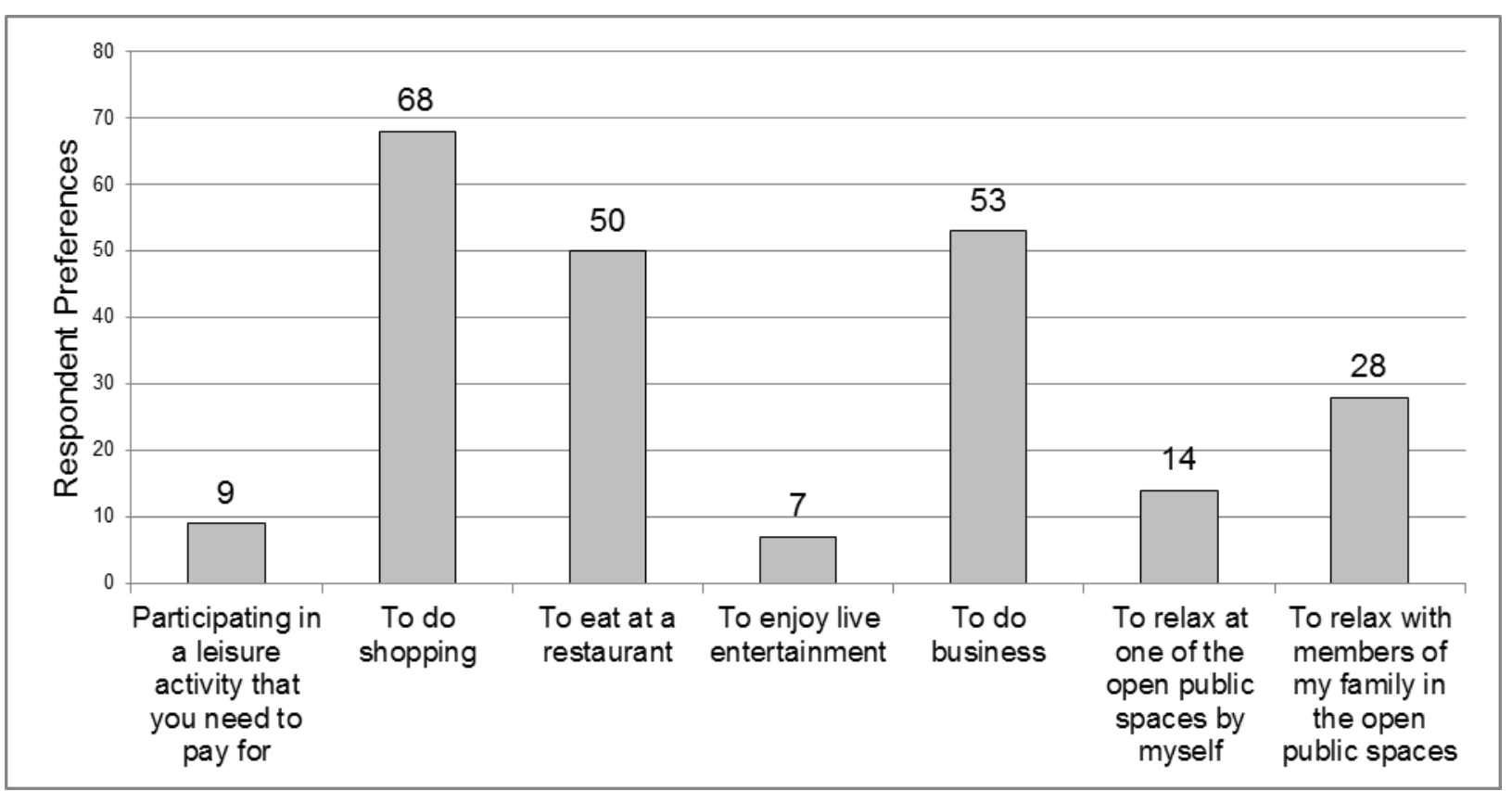

Figure 5b: Reasons why V\&AW employees visit the Waterfront during their free time. 


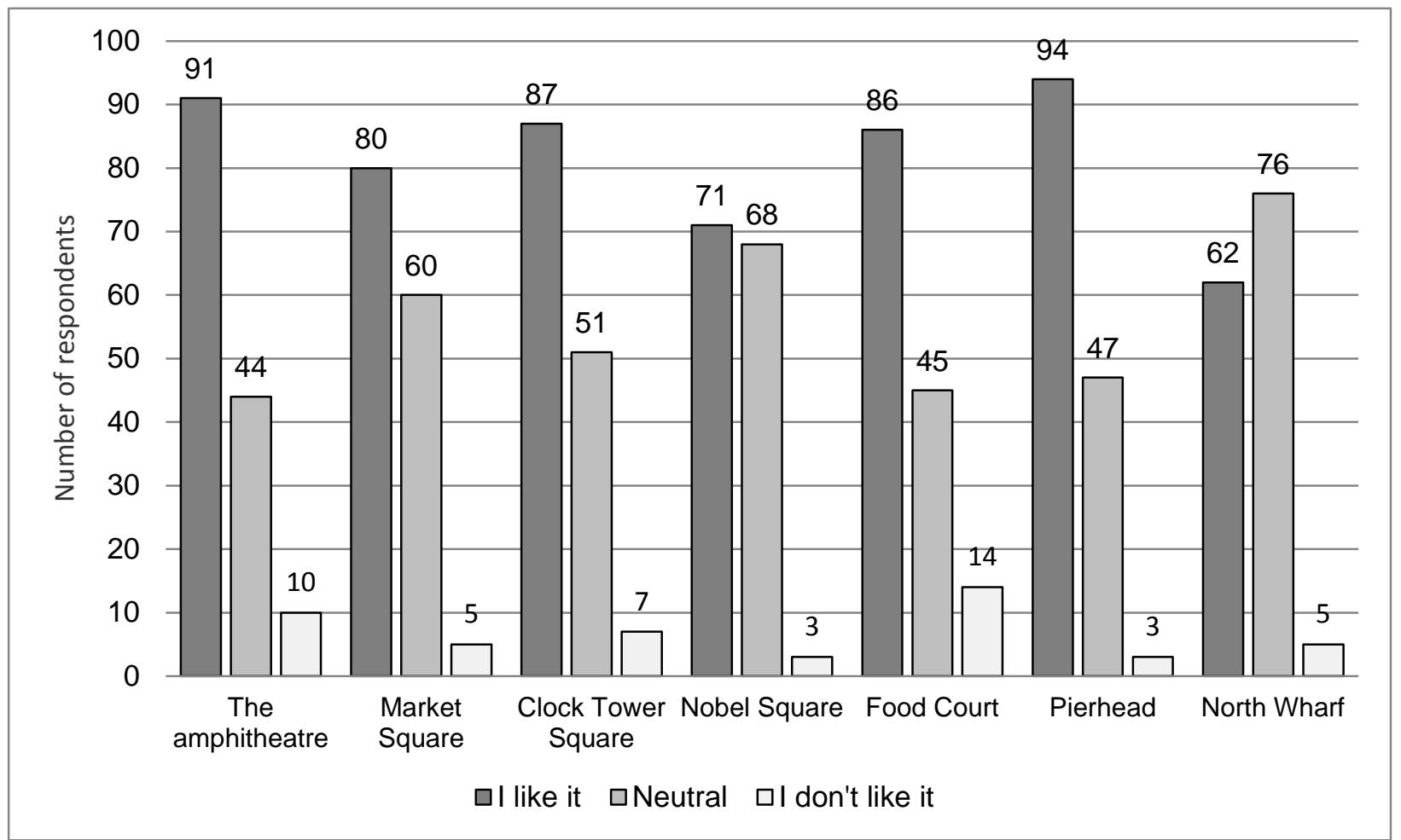

Figure 6a: Capetonians' liking of public spaces in the V\&AW

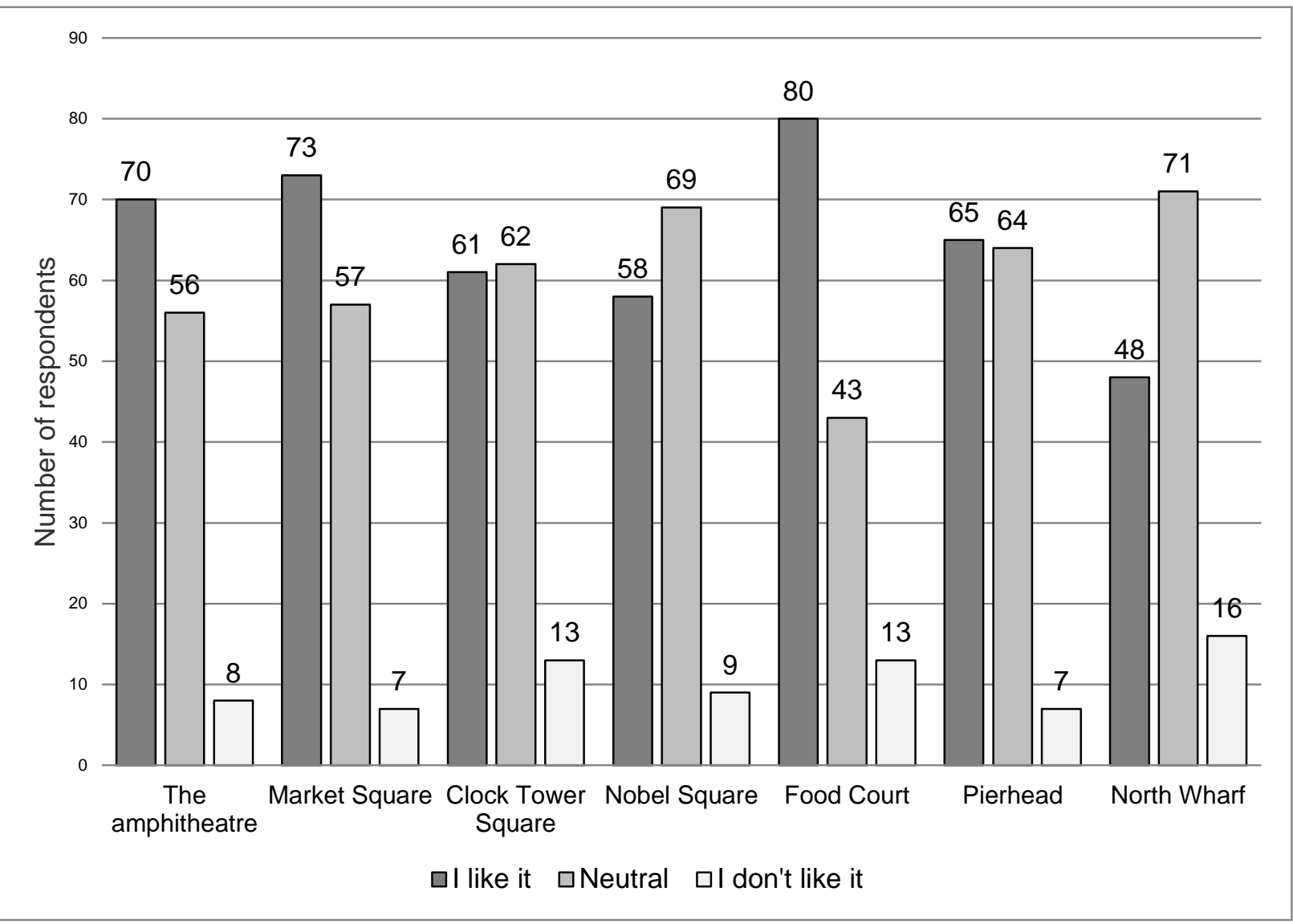

Figure 6b: Employees - Public space preferences in the V\&AW 
Local visitors and employees responded differently. Most of the local visitors like the Pier Head, Amphitheatre and Clock Tower Square, whereas most employees like the Food Court, Market Square and Amphitheatre. Both groups felt neutral about North Warf and Nobel Square. A small number of local visitor respondents did not like the Food Court, Amphitheatre and Clock Tower Square. A small number of employee respondents did not like North Wharf, Clock Tower Square and the Food Court. Figures 6a and 6b indicate large numbers of 'neutral' responses and the researchers wondered if this was an indication of mixed feelings or an inability to decide.

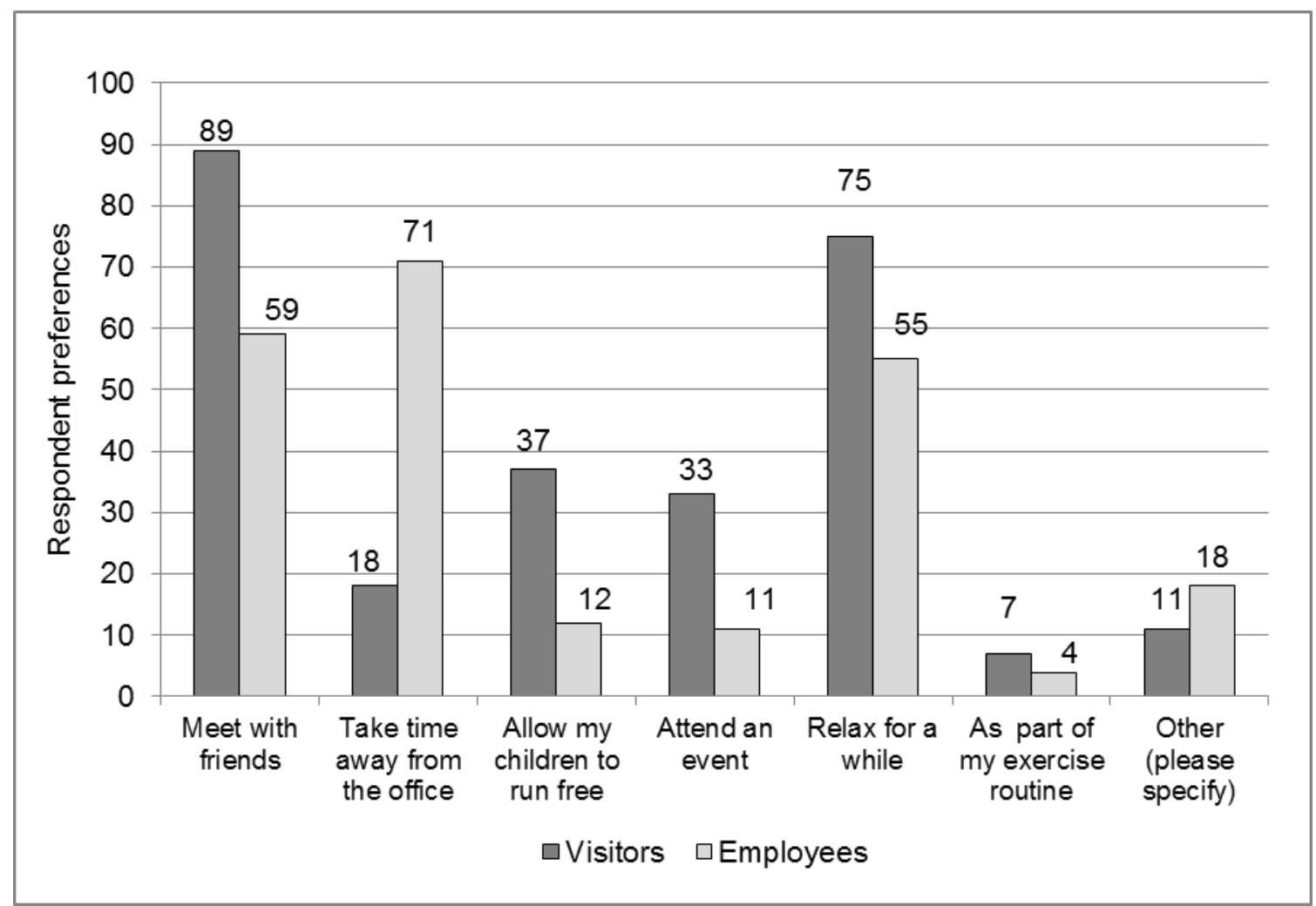

Figure 6c: Reasons for visiting public spaces at the V\&AW.

The public spaces close to the Victoria Wharf Shopping Centre, Amphitheatre and Food Court appear to be the most popular and have the highest footfall and use. Areas farther away from the central development are experienced to be quiet, not user-friendly and offer little attraction for visiting (V\&AW 2014). Respondents were asked about their reasons for visiting the public spaces (Figure 6c). The three main reasons given by local visitors were to meet friends, to relax for a while and allow for children to run freely. The employees visit the public spaces to take time away from the office, meet friends and relax. Overall the respondent's use the public areas at the V\&A Waterfront for relaxation and as meeting places. Respondents were also asked what changes could be made to public areas to encourage more use. Both groups suggested the addition of benches, availability of free Wi-Fi and improved landscaping (Figure 6d). It is noteworthy that a stronger and more visible security presence did not rate highly. 


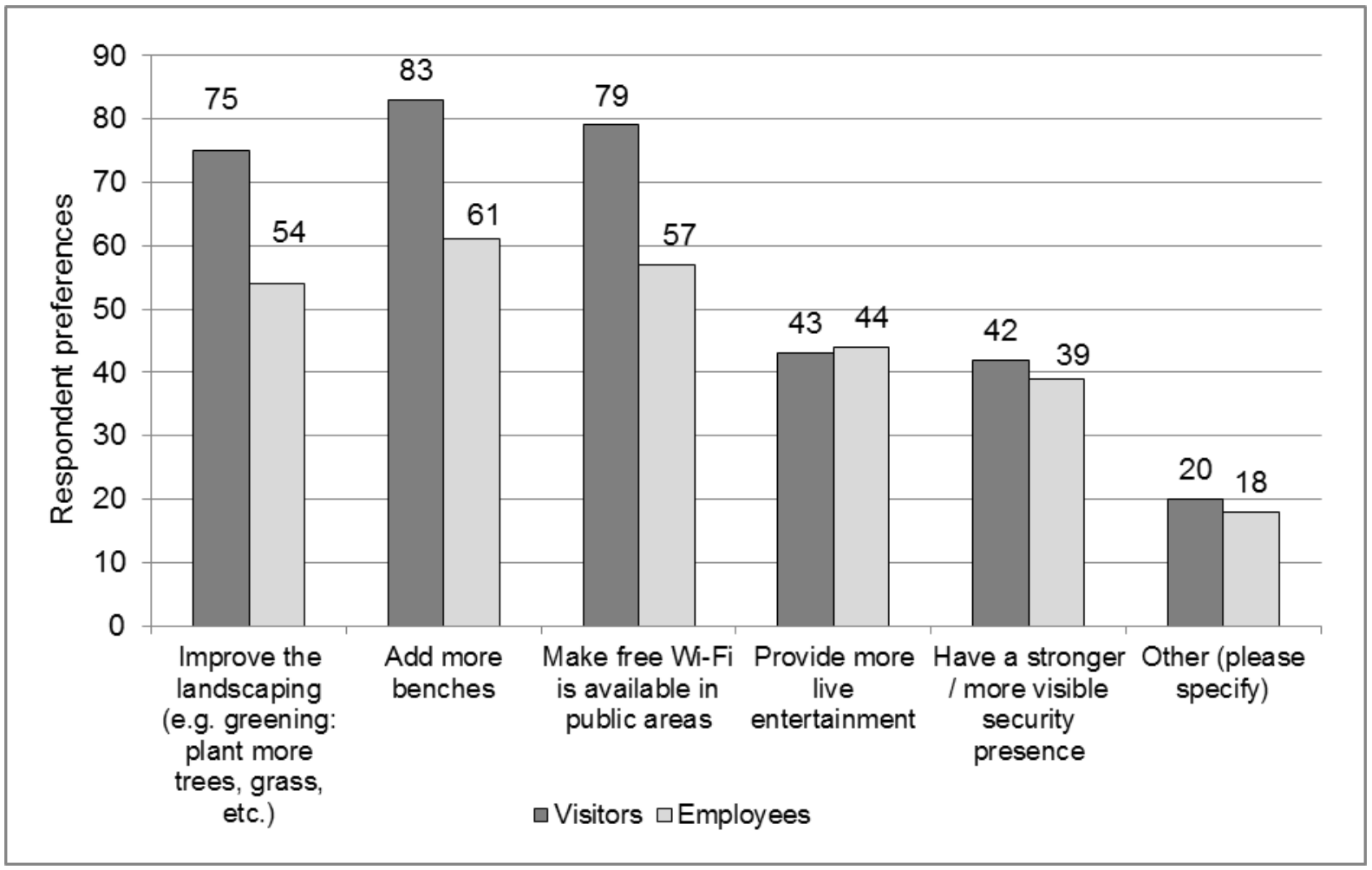

Figure 6d: Ways to encourage users to frequent the public spaces in the V\&AW more.

The V\&AW has often been reported by the media as a tourist trap and not accessible to local visitors. Houssay-Holzchuch and Teppo (2009) have branded the V\&AW as a colonial development aimed at a white audience. The V\&AW Marketing Department has been making concerted efforts to change such adverse perceptions (Cole 2014). Consequently, respondents were asked how inclusive and affordable they perceive the V\&AW to be, whether they are proud to be associated with the V\&AW and if they are willing to take their friends and family with them to spend time at the V\&AW by indicating their agreement or not with a set of nine statements. Figures $7 \mathrm{a}$ and $7 \mathrm{~b}$ detail the results.

The local visitors strongly agree that all population groups were welcome at the V\&AW. Affordability is, however, a concern as local visitors hold that shopping options and leisure activities are not affordable. Answers to the open-ended questions reveal that parking and shops are too expensive, the shops are too 'touristy'and the steap hotel tariffs deter locals from sleeping over in the V\&AW. Some respondents observed that there are too many homeless people in and around the V\&AW's public spaces and that their presence has an adverse effect on the sense of place of these areas. Local visitors agree that the Food Court and Craft Markets offer affordable options. They also feel very strongly about their association with the V\&AW as a place that provides positive memories and with which they are proud to be associated. Employees have similar views with the exception that they deem the leisure activities to be affordable. Even though Capetonian visitors are critical they are loyal supporters and are proud to be associated with the V\&AW. The respondents were further asked to comment about the types of shops in the waterfront to make proposals for expanding the variety to encourage them to visit and shop there more often. Table 2 records the responses. 


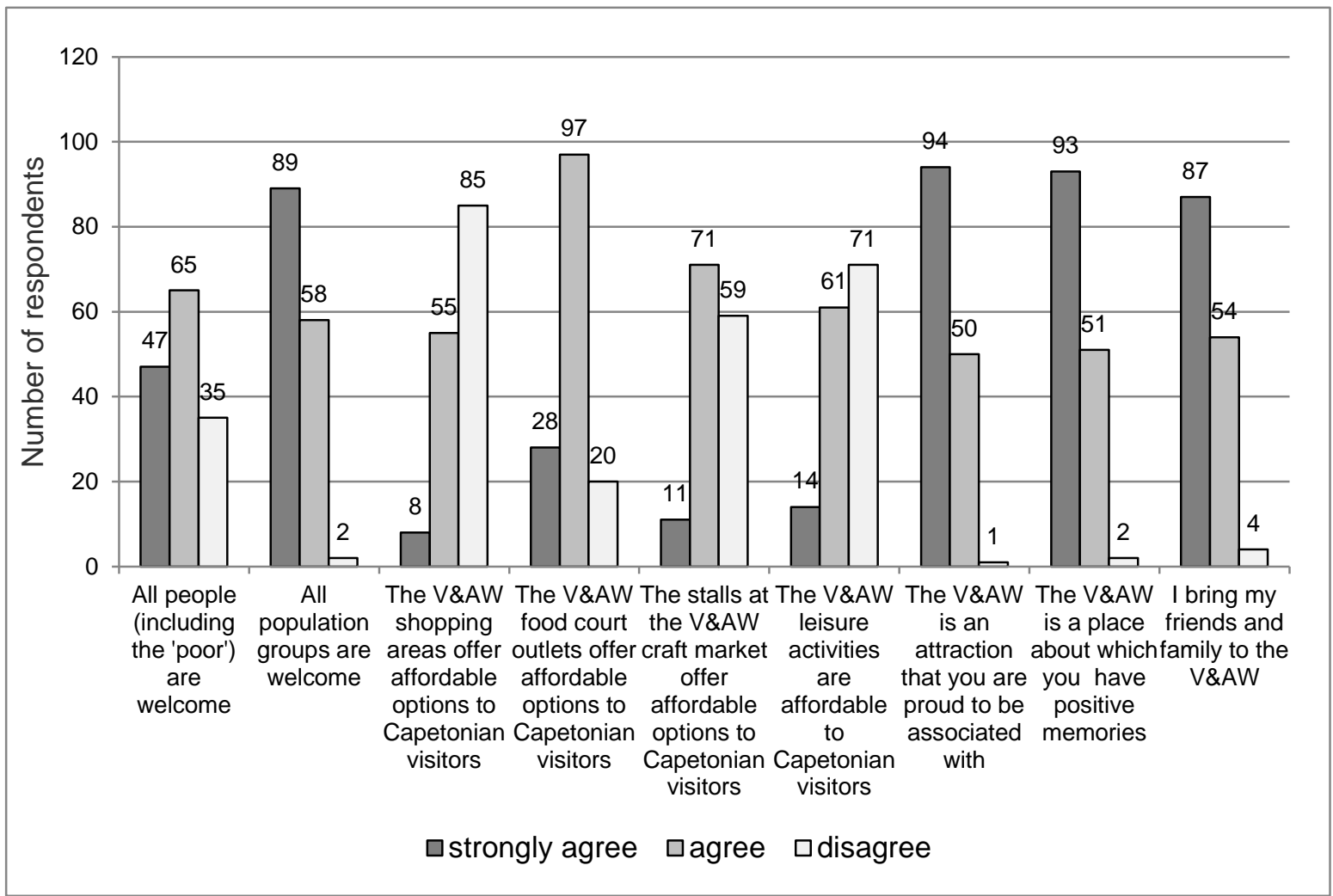

Figure 7a: Visitors' perceptions of the V\&AW.

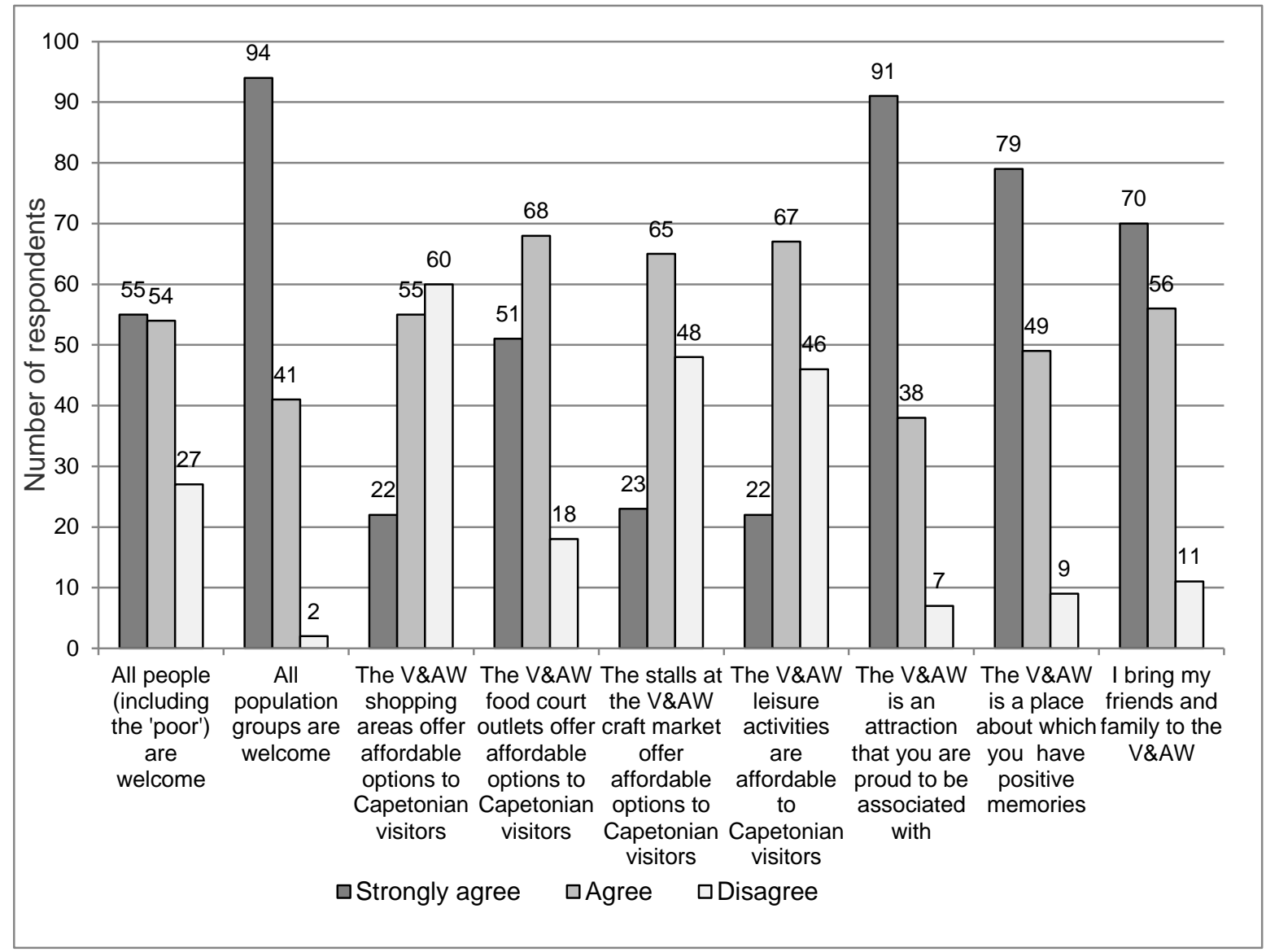

Figure 7b: Employee perception of the V\&AW 
Table 2: Remarks about the existing shops and suggestions for types of shops to be added to the V\&AW

Not sure about the kind of shops, but definitely more cost-effective shops (specifically for the locals)

Affordable ones and a 'real' produce market would have been nice...the current one is way too formal and is more like open-plan shops ... you need a "real" Fish Monger/Fish Market on the scale of those in Asia.

Local designers

Big Blue Proudly South African shops with local products

Current offering is good and diverse; don't feel like there are too many additional shops that would make me visit more often.

More affordable ones...only catering for the overseas tourists as far as pricing is concerned

Spar

More affordable lifestyle shops

The designer shops only cater for tourists - locals cannot buy there. In terms of home ware: I think they should consider adding Mr Price Home

Fashion boutiques Jewellery

As for shops, more farmers market-type areas

No additional shops/stores are needed. The V\&A W has a unique mixture of brands/stores/shops including food stores - catering for local visitors and tourists alike

Labels like Cotton On would definitely attract me to the V\&AW to shop more often

Mid-range international brands like H\&M or Shoe brands

There is an excellent mix of shops and shopping at the V\&A. It does seem quite curio driven but that is just perception. From a personal perspective, I'd like to see a good pet shop, a good home ware and furniture store and more medical services such as doctors consulting rooms (I know that there is a dental practice on site). Also, I trek out to Kalk Bay and Hout Bay for their fish markets... Cape Town Fish Market is too expensive; a real fish market would add some awesome authenticity as would a flower market

More affordable service providers

Golf shops

If the waterfront could have a Dis-chem, a Sportsman's Warehouse and a Mr Price I would never need to go anywhere else

None. The traffic is more of a problem and keeping me away from the centre

More affordable, the V\&A is losing its authenticity with all the International brands - support more local chains

The shops there are pretty cool, a lot of the clothing shops are very expensive branded shops but if I had the money to shop there I would

I personally wouldn't shop there on a regular basis because it is too far from where I live. I like the shops that are there now and occasionally when necessary for me to acquire something specific I will go there. Generally I find that mall geared more for tourists and the upper-middle-class type people. That is part of its charm

I rarely shop here, only in extreme cases if the shop isn't at other malls, or if this is the only mall I can find a particular item. I find it to be more expensive for a product than for the same item at another mall

Local restaurants selling traditional

Unique but affordable homeware, fashion, decor

Bicycle shop

None. The waterfront is not my closest 'store', so for everyday shopping, I would not choose to go to the V\&A specifically

Something like a Food Lover's Market

More child-friendly restaurants and safe controlled playing areas

Wimpy

Respondents were asked to suggest leisure activities that should be added to the V\&AW's product portfolio to encourage visits. The range of proposals included areas (indoor and outdoor) for children; walking tours linked to the heritage aspects of the Waterfront; water sports or water-based events (e.g. boat shows, powerboat racing); controlled picnic or beach braai spots; a theme park with rides; fashion parades; more local music like the 'Kaapse Klopse'; tours on working boats; music shows; supervised area for children; petting zoo; a gymnasium; drive-in cinema; jazz festival; live evening entertainment; more food markets; transport to and from parking garages for people with small children and for older people; and art exhibitions of any sort. The long and varied list of suggestions indicate that a popular 
leisure space like the V\&AW can always improve and that local visitors indicated certain gaps in the current supply of leisure opportunities that can be filled in future. Finally, respondents were asked to name their favourite shopping centres in Cape Town. Their two most popular shopping centres are Canal Walk (75\%) and the V\&AW (25\%).

\section{Conclusions and recommendations}

The V\&AW is the most visited tourist destination in South Africa, with over 24 million visitors in 2013, of whom more than half originate from the greater Cape Town metropolitan area. Over 16, 000 people work in the V\&AW daily. These large numbers of visitors and employees rank the V\&AW as an important leisure and working space for Capetonians and a keystone of the economy of the city and the region. Visitors and employees enjoy the products (leisure and retail), services and experiences that this mixed-use development offers as well as the pleasant memories the V\&AW inspires. Some Capetonians still perceive it as a playground for high income earners. Realities concerning the unaffordability (of certain highend shops, hotels and restaurants) persist and these are widely criticised, yet serve as a reminder that Cape Town is a World-class city competing to attract affluent local and international tourists to the best 'shoppertainment' experience an Africa city can offer. Capetonions perceive the V\&AW and its public spaces as welcoming and open to all. The public open spaces are perceived by Capetonians as welcoming and open to all with some preferred over others. Capetonians are proud to be associated with this destination and are willing to showcase the property to their visiting friends and family. Given the rapid diminishing of available public open spaces the V\&AW in Cape Town is a backyard for local visitors and employees that is functional for the community it serves and retains the special link between the ocean and the city where locals feels welcome and take ownership of the available public spaces. The V\&AW management is striving to dispel the perception of the venue as a tourist trap where Capetonians feel alienated. They have recognised the need to cater for both the local and tourist markets (domestic and international) in their belief that visitors will seek out the places favoured and frequented by locals (Van Zyl 2006).

\section{Acknowledgments}

The authors want to thank Mr Jascha Muller of the Centre for Geographical Analysis at the Department of Geography and Environmental Studies for preparing the final maps and graphs for this article.

\section{References}

Amin, A. (2006) The good city. Urban Studies, 43 (5/6), pp.1009-1023

Birkby, R. (1998) The making of the Victoria \& Alfred Waterfront: The inside story of its planning, design and creation. Cape Town: V\&A Waterfront.

Breen, A. \& Rigby, D. (1996) The waterfront: A worldwide urban success story. London; Thames and Hudson.

Casellas, A., Dot, E., Pallares-Barbera, M. (2012) “Artists, cultural gentrification and public policy”. Urbani Izziv. 23 (1) pp. 104-114.

Cattel, V. Dines, N. Geslerc, W. \& Curtis, S. (2008) Mingling, observing, and lingering: Everyday public spaces and their implications for well-being and social relations. Health \& Place, 14, pp. 544-56.

Cole, C. (2014) Chantal Cole, Marketing manager at the V\&AW. Personal communication, 3 March 2014.

Dublin City Council, (2011) Your city your space: Dublin City Public Realm Strategy. Dublin. 
Eidelman, G.E. (2013) Landlocked: Politics, property, and the Toronto waterfront, 19602000. Phd thesis. Toronto: University of Toronto.

Ferreira, S.L.A. \& Visser, G. (2007) Creating an African Riviera: Revisiting the Impact of the Victoria and Alfred Waterfront Development in Cape Town. Urban Forum, 18, pp. 227246.

Galvin \& Sales (1994). Cape Town Historical Walk-Waterfront: 13.

Gospondini, A. (2006). Portraying, classifying and understanding the emerging landscapes of the post-industrial city. Cities, 23(5), 311-330.

Hoyle, B.S. (1995) A shared space: Contrasted perspectives on urban waterfront developments in Canada, Town Planning Review, 66, pp.345-369.

Hoyle, B.S. (2002) Urban waterfront revitalization in developing countries: The example of Zanzibar's Stone town. The Geographical Journal, 168 (2), pp. 141-162.

Houssay-Holzschuch, M. \& Teppo A. (2009) A mall for all? Race and public space in postapartheid Cape Town. Cultural Geographies, 16 (3), pp.351-379.

Hoyt, L. (2005) Planning through compulsory commercial clubs: Business improvement districts. Economic Affairs, 25(4), pp. 24-27.

Kent, F. (2014) Personal communication between R de Villiers and with Fred Kent from Project Public Spaces (PPS) on the V\&AW and its Public Open Spaces, February 9, 2014.

Kilian, D. \& Dodson, B. (1996) Between the devil and the deep blue sea: Functional conflicts in Cape Town's Victoria and Alfred Waterfront. Geoforum, 27, pp. 495-507.

Kilian, D. Goudie, S. Dodson, B. (1995) Postmodern f(r)ictions: History, text and identity at the Victoria and Alfred Waterfront. Architecture SA, May-June, pp. 26-31.

Lehrer, U \& Laidley, J (2008) Old mega-projects newly ackaged? Waterfront redevelopment in Toronto. International Journal of Urban and Regional Research, 32 (4), pp.786-803.

Lemanski, C. (2005) Proving a mixed-race in post-apartheid urban South Africa: improving the streets or removing unwelcome residents?' Paper presented at 'Ordinary Spaces of Development” session at RGS/IBG Conference, September, London.

Lemanski, C. (2007) Global cities in the South: Deepening social and spatial polarisation in Cape Town. Cities, 24 (6); pp. 448-461.

Lienberg, A. (2014) Personal communication between R de Villiers and A Lienberg on the development of Zeitz MOCAA at the Clock Tower, May 29, 2014.

Madanipour, A. (2004) Marginal Public Spaces in European Cities. Journal of Urban Design, 9 (3); pp. 267-286.

Moolman, G (2013) Events. Personal e-mail communication between Moolman G and R. de Villiers 19 August 2013).

Nikitini, C. (2011) What is the place for public space in our cities? Proceedings of a Conference on Public Space, La Fabrique de la Cité/The City Factory’s, 4 May 2011, Barcelona.

O’Callaghan, C. \& Linehan, D. (2007) Identity, politics and conflict in dockland development in Cork, Ireland: European Capital of Culture 2005. Cities, pp. 311-323.

Orvell, M. \& Meike, J.L. (2009) Public Space and the Ideology of Place in American Culture: Architecture Technology Culture. Amsterdam: Rodopi.

Pirie, G. H. (2007) Reanimating a comatose goddess: Reconfiguring central Cape Town. Urban Forum, 18(3), pp.125-151.

Quinn, K.J. (2012) Sustainable Urban Waterfront: Re-imagining waterfronts as inclusive public spaces. Master's thesis. Arizona: The University of Arizona, Department of Landscape Architecture.

Robinson, P. (2012) Good quality public spaces. Proceedings from the discussion summary segment 3 of the World Urban Forum conference held 1 - 7 September 2012, Naples, Italy. 
Rogerson, C. M. (1997) Local economic development and post-apartheid reconstruction in South Africa. Singapore Journal of Tropical Geography, 18(2), pp.175-195.

Rogerson, C. M. (1999) Local economic development and urban poverty alleviation: The experience of post-apartheid South Africa - lessons on demand. Habitat International, 13(4), pp.511-534.

Rogerson, C. M. (2006) Creative industries and urban tourism: South African perspectives. Urban Forum, 17(2), pp.149-166.

Rogerson, C. M. \& Visser, G. (2006) International tourism flows and urban tourism in South Africa. Urban Forum, 17(2), pp.199-213.

Rogerson, C.M. \& Visser, G (2007). Tourism in urban Africa: Setting the scene. In Urban tourism in the developing world: The South African experience, edited by C.M.

Rogerson \& G. Visser. New Brunswick, London: Transaction Press. pp. 1-9.

Standish, B. Boting, A. Ridgard, C. \& White, J. (2013) Economic contribution of the V\&A Waterfront. Economic Information Services: 1 - 120.

Tonnelat, S. (2010) The sociology of urban public spaces. Territorial evolution and planning solution: Experiences from China and France. Paris: Atlantis Press.

V\&AW (2011) V\&AW facts and figures 2011. Available from: http://www.waterfront.co.za/home/pages/home_introduction.aspx. [Accessed 31 July 2011]

V\&AW (2013) Clock Tower precinct and development plans: 2014-2016. Available from: http://www.waterfront.co.za/home/corporate/pages/corporate_groupofcompanies.aspx. [Accessed 18 August 2013]

V\&AW (2014) Use of public certain public spaces. Available from: http://www.waterfront.co.za/home/pages/home_introduction.aspx. [Accessed 31 July 2011]

Van Zyl, P. S. (2005) The V\&A Waterfront project in Cape Town, South Africa - An African success story in the integration of water, working harbour, heritage, urban revitalization and tourism development. Paper presented at Conference on Development and Tourism in Coastal Areas, Sharm El-Sheikh, Egypt, 9-12 March 2005.

Van Zyl, P. S. (2006) From brown to green to gold waterfronts and the future of cities, Paper presented at World Planners Congress, 17-20 June 2006 Vancouver, Canada.

White, C. (2014) V\&AW 2013 Festive Season Trading Results Final January 2014. Unpublished report, V\&AW Company.

Young, I.M. (1995) City life and difference. In: Kasinitz, P. (Ed.), Metropolis: Center and symbol of our times. New York University Press, New York, pp. 250-270.

Young, I. M. (2000) Inclusion and Democracy. New York: Oxford University Press. 